\title{
PURIFICATION AND PROPERTIES OF THE DIHYDROFOLATE SYNTHETASE FROM PEA SEEDLINGS ${ }^{1}$
}

\author{
Kazuo IwAI and Masamichi IKedA ${ }^{2,3}$ \\ Research Institute for Food Science, Kyoto University, Uji, Kyoto 611, Japan
}

(Received December 10, 1974)

\begin{abstract}
Summary Dihydrofolate synthetase [EC 6.3.2.12] was extracted from the cell particles (mitochondrial fraction) of pea seedlings and purified about 2,000-fold by ammonium sulfate fraction, DEAE-cellulose column chromatography, Sephadex G-200 gel filtration, and hydroxylapatite column chromatography. The enzyme preparation obtained was confirmed ultracentrifugally to be in the homogeneous state. The sedimentation coefficient of this enzyme was calculated as $3.9 \mathrm{~S}$. The apparent molecular weight of the enzyme was determined to be about 56,000 .

Optimum $\mathrm{pH}$ for the reaction was 8.8. The enzymatic reaction required dihydropteroate, L-glutamate and ATP as substrates, and divalent $\left(\mathrm{Mg}^{2+}\right.$ or $\left.\mathrm{Mn}^{2+}\right)$ and univalent $\left(\mathrm{K}^{+}, \mathrm{NH}_{4}{ }^{+}\right.$or $\left.\mathrm{Rb}^{+}\right)$cations as cofactors. The enzyme was specific for dihydropteroic acid as the substrate. ATP was not replaceable with any other nucleotides. $K_{m}$ values for dihydropteroate, L-glutamate, ATP, $\mathrm{Mg}^{2+}$, and $\mathrm{Mn}^{2+}$ were $1.0 \times 10^{-6}, 1.5 \times 10^{-3}$, $1.0 \times 10^{-4}, 1.1 \times 10^{-3}$, and $6.3 \times 10^{-5} \mathrm{M}$, respectively. The enzymatic reaction was inhibited by the addition of ADP, but not by AMP. This suggests that the product from ATP in the reaction is composed of $\mathrm{ADP}+\mathrm{P}_{\mathrm{i}}$.
\end{abstract}

Thus, it is proposed that this enzyme catalyzes the following reaction:

$$
\text { Dihydropteroic acid + L-glutamic acid + ATP } \frac{\mathrm{Mg}^{2+}\left(\text { or } \mathrm{Ma}^{2+}\right)}{\mathrm{K}^{+}\left(\text {or } \mathrm{NH}_{4}^{+} \text {or } \mathrm{Rb}^{+}\right)}
$$

$$
\text { Dihydrofolic acid }+ \text { ADP }+\mathbf{P}_{\mathrm{i}} \text {. }
$$

${ }^{1}$ The biosynthesis of folic acid compounds in plants, VIII (for Part VII, see Reference (11)). Part of this report was presented at the Annual Meeting of the Agricultural Chemical Society of Japan at Meiji-gakuin University on April, 1969 and at the Fourth International Symposium on Pteridines at Toba, on July 23, 1969. This work was supported in part by a grant-in-aid (to K. I.) for scientific research from the Ministry of Education.

2 Present address: Faculty of Nutrition, Kobe-gakuin University, Tarumi, Kobe 673, Japan.

3 岩井和夫, 池田雅充 
Previous investigations $(1,3)$ have shown that the probable intermediate in the biosynthesis of folate compounds in plants is dihydropteroic acid, which combines enzymatically with L-glutamic acid to form dihydrofolic acid, and that the enzyme (dihydrofolate synthetase), which catalyzes the condensation of dihydropteroic acid and L-glutamic acid, was partially purified from pea seedlings (3).

GRIFFIN and BROWN (2) have reported the occurrence and partial purification of the enzyme from Escherichia coli. The high purification of the enzyme from microorganisms and higher plants was difficult, since the enzyme is fairly labile. We described in the previous report (11) that the high enzyme activity located in the cell particles (mitochondrial fraction) of pea seedlings and the enzyme extracted from the cell particles was relatively stable compared with that extracted from the cell homogenates.

Thus, in this paper, an attempt to extract and highly purify from the cell particles was carried out and the properties of the enzyme were investigated.

\section{MATERIALS AND METHODS}

Chemicals. ATP, GTP, ITP, CTP, UTP, ADP, and AMP were purchased from the Sigma Chemical Company. Albumin from bovine serum, ovalbumin, chymotrypsinogen A from beef pancreas, and myoglobin from the sperm whale were from Schwarz/Mann. DEAE-cellulose was from the Brown Company and Sephadex G-200 was from Pharmacia Fine Chemicals. Pteroic acid was the gift of Dr. G. Toennies and Dr. John A. King. Pteroic acid was reduced to dihydro form with sodium dithionite by the method of FUTTERMAN (4), and to the tetrahydro form by hydrogenation in glacial acetic acid according to the directions of O'Dell et al. (5).

Standard assay conditions. The reaction mixtures contained Tris- $\mathrm{HCl}$ buffer (100 $\mu$ moles, $\mathrm{pH} 8.8)$, magnesium sulfate (5.0 $\mu$ moles), L-glutamic acid (5.0 $\mu$ moles); 2-mercaptoethanol (50 $\mu$ moles); ATP $(1.0 \mu$ mole), enzyme $(1.2 \mu \mathrm{g})$, and dihydropteroic acid $(0.05 \mu$ mole $)$ in a final volume of $1.0 \mathrm{ml}$. The reaction was carried out at $37^{\circ} \mathrm{C}$ for $30 \mathrm{~min}$, then was stopped by heating the entire mixture in a boiling water bath for one minute. After diluting the reaction mixture with cold water, the amount of dihydrofolate formed was determined by microbiological assay with Lactobacillus casei ATCC 7469 in $10 \mathrm{ml}$ of an assay medium for folic acid (7). Amounts are expressed as folate equivalents. One unit of dihydrofolate synthetase catalyzes the formation of 0.1 nmole of folate equivalent per 30 min under standard assay conditions. The specific activity of dihydrofolate synthetase is expressed in terms of units per mg protein.

Determination of protein. The amount of protein was determined by the method of Lowry et al. (6), using crystalline bovine serum albumin as the standard.

Germination of pea seeds. Air-dried, healthy pea seeds (Pisum sativum L. var. Alaska) were soaked in distilled water at $25^{\circ} \mathrm{C}$ for $18 \mathrm{hr}$, then were allowed to ger- 
minate in a greenhouse at $20^{\circ} \mathrm{C}$ for 6 days on moist absorbent cotton in a vat covered with a wet filter paper.

\section{RESULTS AND DISCUSSION}

\section{Purification of the dihydrofolate synthetase from pea seedlings}

Step I. Purification of the enzyme directly extracted from whole pea seedlings was difficult because the enzyme is labile, as previously reported (3). However, the enzyme extracted from particles (mitochondrial fraction) is fairly stable (11), so we used this extraction of the enzyme. The medium used to isolate the cell particles contained $0.5 \mathrm{M}$ sucrose, $0.05 \mathrm{M}$ Tris- $\mathrm{HCl}$ buffer at $\mathrm{pH} 7.5$ and $50 \mathrm{~mm}$ 2-mercaptoethanol. Six-day-old seedlings $(100 \mathrm{~kg})$ were homogenized with 100 liters of the isolation medium. This and all subsequent steps were performed at $0-5^{\circ} \mathrm{C}$, except where otherwise noted. The homogenate was squeezed through cotton cloth by basket centrifugation, and the green juice (130 liters) was collected.

Step II. After the juice which had stood for more than $2 \mathrm{hr}$ to remove debris was decanted, the green supernatant solution was centrifuged at $20,000 \times g$ for $30 \mathrm{~min}$. The precipitate was used as the particle fraction (mitochondrial fraction). The precipitate was suspended in 10 liters of $0.01 \mathrm{~m}$ Tris- $\mathrm{HCl}$ buffer at $\mathrm{pH} 7.5$ containing $0.05 \mathrm{~m} 2$-mercaptoethanol for $20 \mathrm{~min}$ with mechanical stirring, and then it was centrifuged at $20,000 \times g$ for $30 \mathrm{~min}$. The supernatant solution was used as the extract of the mitochondrial fraction.

Step III. Solid ammonium sulfate was added to the above extract to give 0.10 saturation. The mixture was equilibrated by stirring for $30 \mathrm{~min}$, then it was centrifuged at $20,000 \times g$ for $30 \mathrm{~min}$. Solid ammonium sulfate was then added to the supernatant solution to give 0.35 saturation. The mixture was again equilibrated by stirring for $30 \mathrm{~min}$, then it was centrifuged at $20,000 \times g$ for $30 \mathrm{~min}$.

Step IV. The resultant precipitate was dissolved in 2.4 liters of $0.01 \mathrm{M}$ Tris- $\mathrm{HCl}$ buffer at $\mathrm{pH} 7.5$ containing $0.05 \mathrm{~m} 2$-mercaptoethanol. Then the solution was divided into six parts of $400 \mathrm{ml}$ each for convenient fractionation on DEAEcellulose. Each $400 \mathrm{ml}$ portion was dialyzed against $0.01 \mathrm{M}$ Tris- $\mathrm{HCl}$ buffer at pH 7.5 containing $0.05 \mathrm{M}$ 2-mercaptoethanol. The resulting precipitate was centrifuged and discarded. Each dialysate was placed in a DEAE-cellulose column $(6 \times 70 \mathrm{~cm})$ previously equilibrated with $0.01 \mathrm{M}$ ammonium sulfate in $0.01 \mathrm{M}$ Tris$\mathrm{HCl}$ buffer at pH 7.5 and $0.05 \mathrm{~m}$ 2-mercaptoethanol. The column was washed with 2 liters of the same buffer and developed by a linear gradient elution. The mixing chamber contained 2 liters of $0.01 \mathrm{~m}$ ammonium sulfate in $0.01 \mathrm{M}$ Tris- $\mathrm{HCl}$ buffer at $\mathrm{pH} 7.5$ and $0.05 \mathrm{M}$ 2-mercaptoethanol, and the reservoir contained 2 liters of $0.2 \mathrm{M}$ ammonium sulfate in the same buffer solution. The enzymatically active elutions from the DEAE-cellulose column were combined, and then the precipitate with ammonium sulfate $\left(0.60\right.$ saturation) was recovered and stored at $0^{\circ} \mathrm{C}$.

Step V. After the precipitate had been dissolved in $100 \mathrm{ml}$ of $0.01 \mathrm{M}$ Tris- $\mathrm{HCl}$ 
buffer at pH 7.5 containing 0.05 м 2-mercaptoethanol, the solution was divided into two parts of $50 \mathrm{ml}$ each for convenient fractionation on a Sephadex. Each $50 \mathrm{ml}$ portion was applied to a Sephadex G-200 column $(6 \times 90 \mathrm{~cm})$ equilibrated with $0.8 \mathrm{M}$ ammonium sulfate in $0.1 \mathrm{M}$ Tris- $\mathrm{HCl}$ buffer at $\mathrm{pH} 7.5$ and $0.05 \mathrm{M} 2$ mercaptoethanol. The same buffer solution was allowed to flow through the column. The enzymatically active elutates were combined and their 0.60 saturation precipitate with solid ammonium sulfate was dissolved in $0.01 \mathrm{M}$ Tris- $\mathrm{HCl}$ buffer at pH 7.5 containing 0.05 м 2-mercaptoethanol.

Step VI. The solution was rechromatographed on a Sephadex G-200 column $(6 \times 90 \mathrm{~cm})$ using the same conditions as in Step V. The enzymatically active elutates were combined and their 0.60 saturation precipitate with solid ammonium sulfate was collected and dialyzed against $0.01 \mathrm{M}$ potassium phosphate buffer at $\mathrm{pH} 7.5$ containing $0.05 \mathrm{~m}$ 2-mercaptoethanol.

Step VII. The dialyzed enzyme solution was applied to a hydroxylapatite column $(4 \times 15 \mathrm{~cm})$ equilibrated with $0.01 \mathrm{M}$ potassium phosphate buffer at $\mathrm{pH} 7.5$ containing $0.05 \mathrm{M} 2$-mercaptoethanol. Elution was carried out with $0.01 \mathrm{M}$ and $0.05 \mathrm{M}$ potassium phosphate buffers at $\mathrm{pH} 7.5$ containing $0.05 \mathrm{M} 2$-mercaptoethanol. The results are shown in Fig. 1. Enzyme fractions in tube number 80 to 96 were pooled, and the precipitate with ammonium sulfate ( 0.60 saturation) was recovered and dissolved in $3 \mathrm{ml}$ of $0.01 \mathrm{M}$ Tris- $\mathrm{HCl}$ buffer at $\mathrm{pH} 7.5$ containing $0.05 \mathrm{M} 2$ mercaptoethanol.

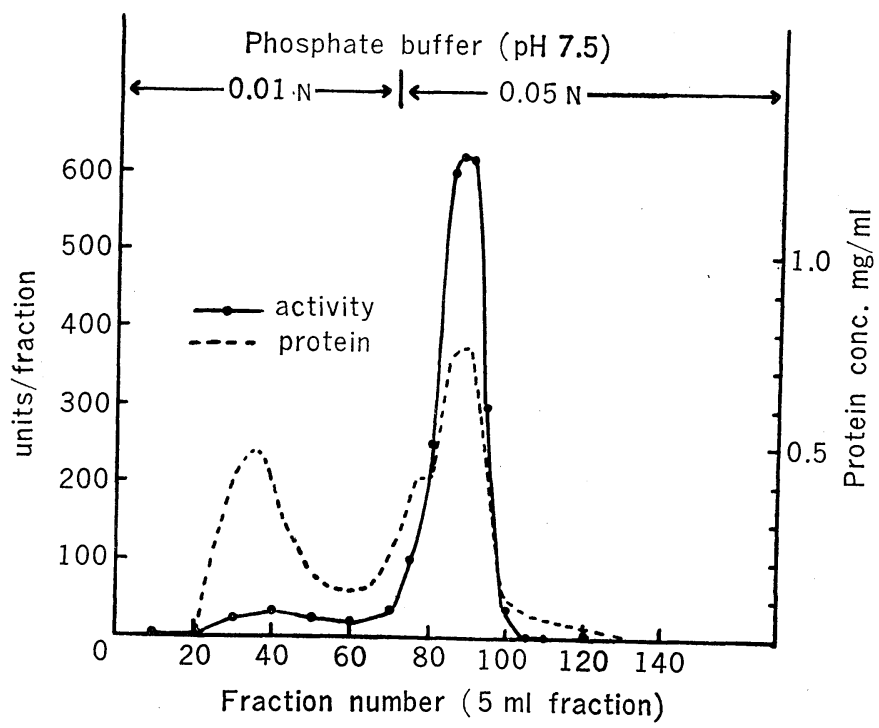

Fig. 1. Elution pattern of the dihydrofolate synthetase from a hydroxylapatite column. The dihydrofolate synthetase fraction obtained by a second Sephadex G-200 treatment was applied to a hydroxylapatite column $(4 \times 15 \mathrm{~cm})$ equilibrated with $0.01 \mathrm{M}$ phosphate buffer at $\mathrm{pH} 7.5$ containing $0.05 \mathrm{M} 2$-mercaptoethanol. Fractions of $5 \mathrm{ml}$ were collected at a flow rate of $10 \mathrm{ml}$ per hour. 
Step VIII. The solution was chromatographed on a Sephadex G-200 column $(2.5 \times 90 \mathrm{~cm})$ under the conditions used for Step V on the Sephadex G-200 column. The elution pattern is shown in Fig. 2. The enzymatically active elutates were

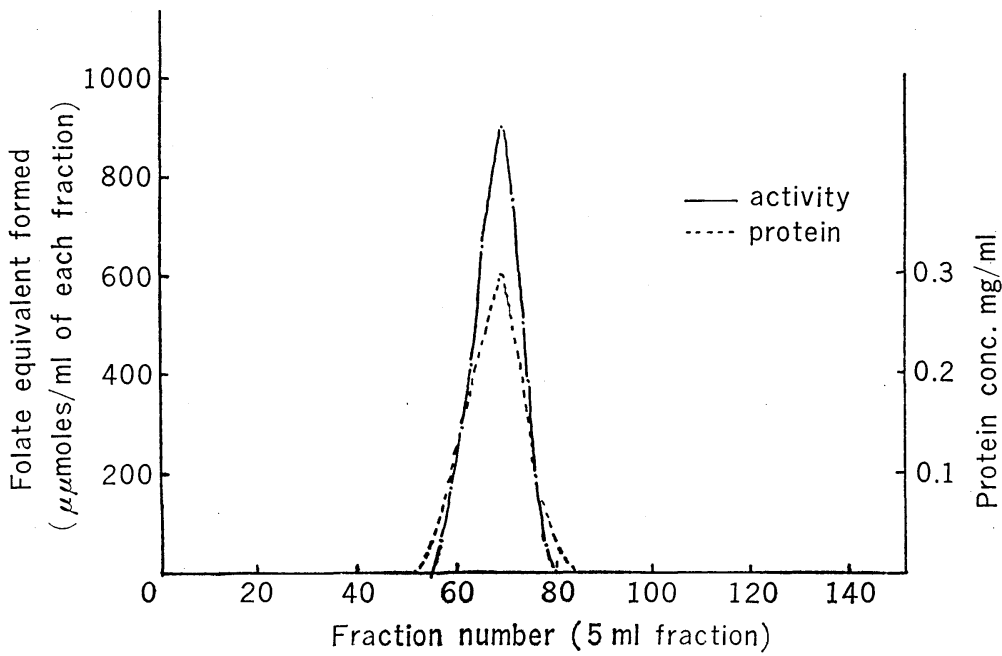

Fig. 2. Third chromatography of dihydrofolate synthetase on a Sephadex G-200. The dihydrofolate synthetase fraction obtained by hydroxylapatite treatment was applied to a Sephadex G-200 column $(2.5 \times 90 \mathrm{~cm})$ equilibrated with $0.8 \mathrm{M}$ ammonium sulfate in Tris-HCl buffer at pH 7.5 and $0.05 \mathrm{~m}$ 2-mercaptoethanol. Fractions of $5 \mathrm{ml}$ were collected at a flow rate of $25 \mathrm{ml}$ per hour.

Table 1. Summary of the purification of the dihydrofolate synthetase from pea seedlings.

\begin{tabular}{|c|c|c|c|c|c|}
\hline Fraction & $\begin{array}{l}\text { Total } \\
\text { protein } \\
\text { (mg) }\end{array}$ & $\begin{array}{l}\text { Total } \\
\text { activity } \\
\text { (units }^{2} \text { ) }\end{array}$ & $\begin{array}{c}\text { Specific } \\
\text { activity } \\
\text { (units } / \mathrm{mg} \text { ) }\end{array}$ & $\begin{array}{l}\text { Purifi- } \\
\text { cation } \\
\text { (ratio) }\end{array}$ & $\begin{array}{l}\text { Yield } \\
(\%)\end{array}$ \\
\hline I. Juice & $4,128,000$ & 477,300 & 0.116 & 1.0 & 100 \\
\hline $\begin{array}{l}\text { II. Extracts of } \\
\text { mitochondrial fraction }\end{array}$ & 698,000 & 321,556 & 0.460 & 4.0 & 67.3 \\
\hline $\begin{array}{l}\text { III. } \mathrm{Am}_{2} \mathrm{SO}_{4} \text { ppt. } \\
(0.1 \sim 0.35 \text { sat. })\end{array}$ & 129,000 & 162,540 & 1.26 & 10.9 & 34.1 \\
\hline $\begin{array}{l}\text { IV. DEAE-cellulose column } \\
\text { chromatography }\end{array}$ & 4,930 & 32,045 & 6.50 & 56.1 & 6.7 \\
\hline $\begin{array}{l}\text { V. 1st chromatography on } \\
\text { Sephadex G-200 }\end{array}$ & 727 & 9,742 & 13.4 & 115.5 & 2.0 \\
\hline $\begin{array}{l}\text { VI. 2nd chromatography on } \\
\text { Sephadex G-200 }\end{array}$ & 100 & 8,560 & 85.6 & 738.0 & 1.8 \\
\hline $\begin{array}{l}\text { VII. Hydroxylapatite } \\
\text { column chromatography }\end{array}$ & 45 & 8,190 & 182 & 1569.0 & 1.7 \\
\hline $\begin{array}{l}\text { VIII. 3rd chromatography on } \\
\text { Sephadex G-200 }\end{array}$ & 30 & 6,840 & 228 & 1965.6 & 1.4 \\
\hline
\end{tabular}

a 1 unit $=0.1$ nmole of folate equivalent formed per 30 min under standard assay conditions. 
combined and their 0.60 saturation precipitate with ammonium sulfate was dissolved in $0.01 \mathrm{M}$ Tris- $\mathrm{HCl}$ buffer at $\mathrm{pH} 7.5$ containing $0.05 \mathrm{M}$ 2-mercaptoethanol. Solid ammonium sulfate was added to the solution ( 0.60 saturation) and the whole was stored at $0^{\circ} \mathrm{C}$ as the purified enzyme precipitation. Purification steps and the yields of dihydrofolate synthetase from pea seedlings are summarized in Table 1.

Ultracentrifugal analysis and the apparent molecular weight of the enzyme

The homogeneity and sedimentation constant of the purified enzyme were

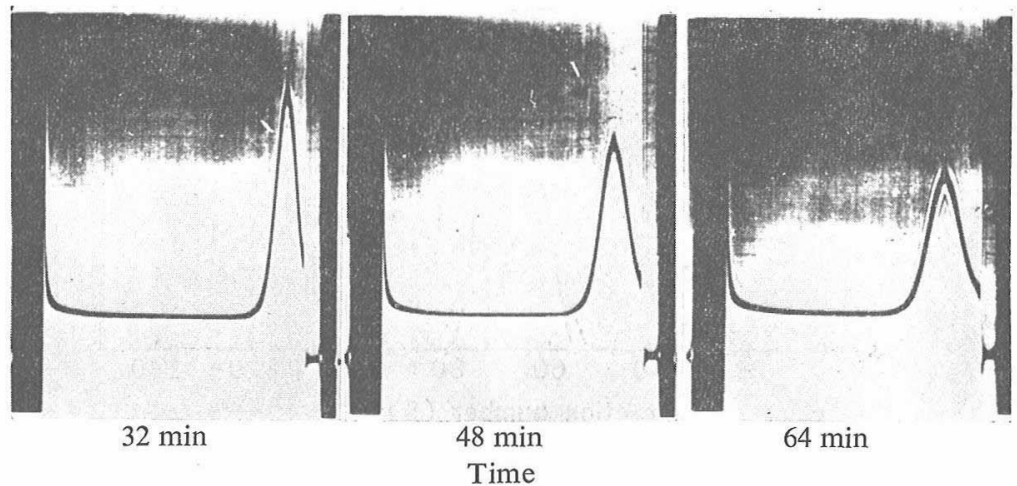

Fig. 3. Sedimentation patterns of the dihydrofolate synthetase from pea seedlings. The sample contained $1.2 \%$ enzyme, $0.1 \mathrm{M} \mathrm{KCl}, 0.01 \mathrm{MET}$, and $0.01 \mathrm{M}$ potassium phosphate buffer at $\mathrm{pH} 7.5$. The determination was carried out at $5.1^{\circ} \mathrm{C}$ and at $52,640 \mathrm{rpm}$.

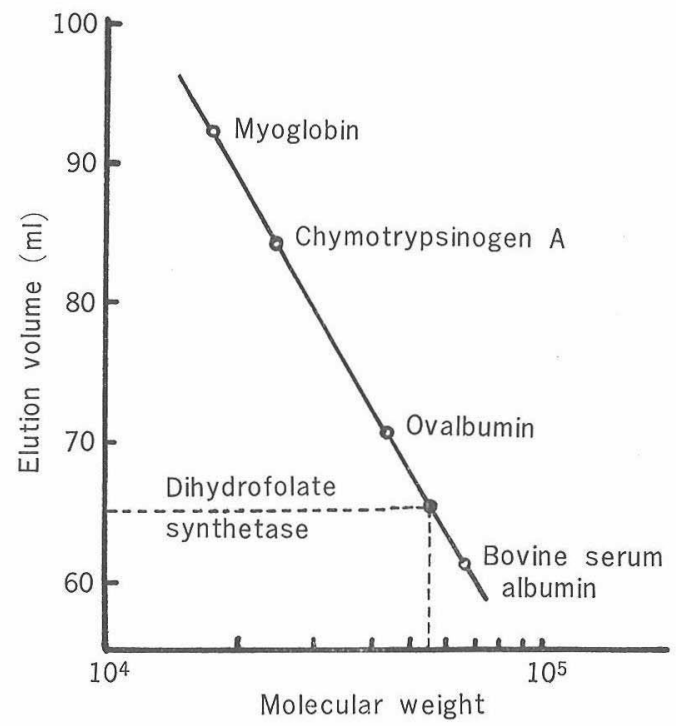

Fig. 4. Plot of elution volume against $\log$ molecular weight for proteins on a Sephadex G-100 column $(1.5 \times 84 \mathrm{~cm})$. 
tested using sedimentation analysis with a Spinco Model E ultracentrifuge. The enzyme preparation was dialyzed overnight against $0.01 \mathrm{M}$ potassium phosphate buffer at $\mathrm{pH} 7.5$ in $0.1 \mathrm{M} \mathrm{KCl}$ and $0.01 \mathrm{~m} 2$-mercaptoethanol at $5^{\circ} \mathrm{C}$. Sedimentation patterns at a maximum speed of $52,640 \mathrm{rpm}$ are shown in Fig. 3. The enzyme preparation showed a homogeneous peak. The calculated sedimentation coefficient at $20^{\circ} \mathrm{C}$ was about $3.9 \mathrm{~S}^{4}$. The apparent molecular weight of the enzyme was determined according to the method of ANDREws (8), using a Sephadex G-100 $(1.5 \times 70 \mathrm{~cm}$ ). Bovine serum albumin (mol. wt. 67,000), ovalbumin (mol. wt. 45,000), chymotrypsinogen A from beef pancreas (mol. wt. 25,000), and myoglobin from the sperm whale (mol. wt. 17,800) were used as the reference standards. When compared with the reference standards, the molecular weight of the dihydrofolate synthetase from pea seedlings seems to be about 56,000, as shown in Fig. 4. After the enzyme preparation had been stored at $0^{\circ} \mathrm{C}$ for 3 months in $0.01 \mathrm{M}$ Tris$\mathrm{HCl}$ buffer at $\mathrm{pH} 7.5$ containing $2 \mathrm{M}$ ammonium sulfate and $0.05 \mathrm{M} 2$-mercaptoethanol, it was applied to a Sephadex G-100 column. The elution pattern is shown in Fig. 5. The new protein peak which had no enzyme activity appeared in fractions 29 to 34 . The apparent molecular weight was about 120,000. The main peak was active for enzyme activity, and its molecular weight was 56,000. This indicates that the non-active peak may be a dimer of the active enzyme and may be formed during storage of the enzyme. The value of the sedimentation coefficient (7.5 S), which we previously reported (10), was thought to be the value of the nonactive dimer.

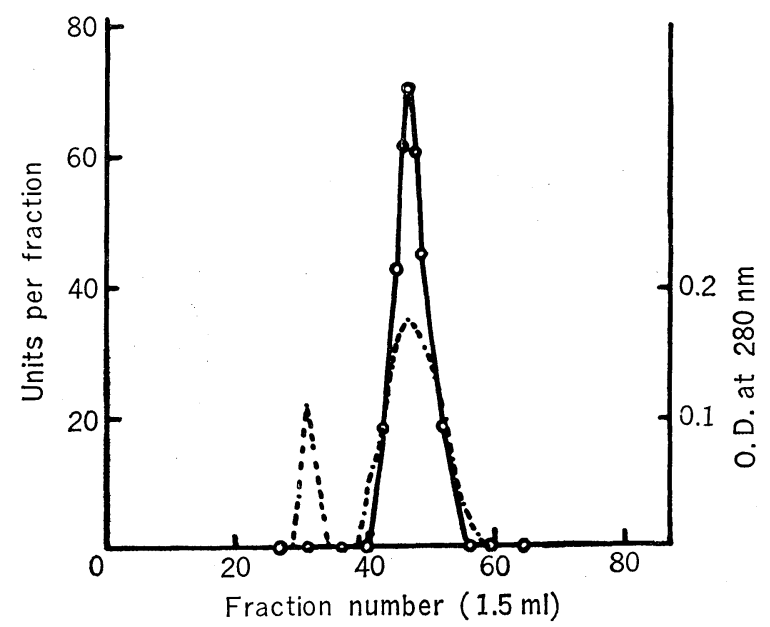

Fig. 5. Chromatography of purified dihydrofolate synthetase on a Sephadex G-100. The purified enzyme preparation which had been stored at $0^{\circ} \mathrm{C}$ for 3 months in a $0.01 \mathrm{M}$ Tris- $\mathrm{HCl}$ buffer, $\mathrm{pH} 7.5$, containing $0,05 \mathrm{M} 2$-mercaptoethanol and $2 \mathrm{M}$ ammonium sulfate, was used. O---O, O.D. at $280 \mathrm{~nm}$; O-O, activity.

4 In a previous report, the sedimentation coefficient was reported to be $7.5 \mathrm{~S}$ (10). Further repeated experiments, however, indicated that it is $3.9 \mathrm{~S}$. 
Ultraviolet absorption spectrum of the enzyme

The ultraviolet absorption spectrum of the enzyme in $0.01 \mathrm{M}$ Tris- $\mathrm{HCl}$ buffer at $\mathrm{pH} 7.5$ containing $0.005 \mathrm{M} 2$-mercaptoethanol is presented in Fig. 6. The enzyme shows a single absorption peak with a maximum at $278 \mathrm{~nm}$ and a minimum at $250 \mathrm{~nm}$. The extinction coefficient $\left(E_{1 \mathrm{~cm}}^{1 \%}\right)$ value of the enzyme at $280 \mathrm{~nm}$ was 10.8 .

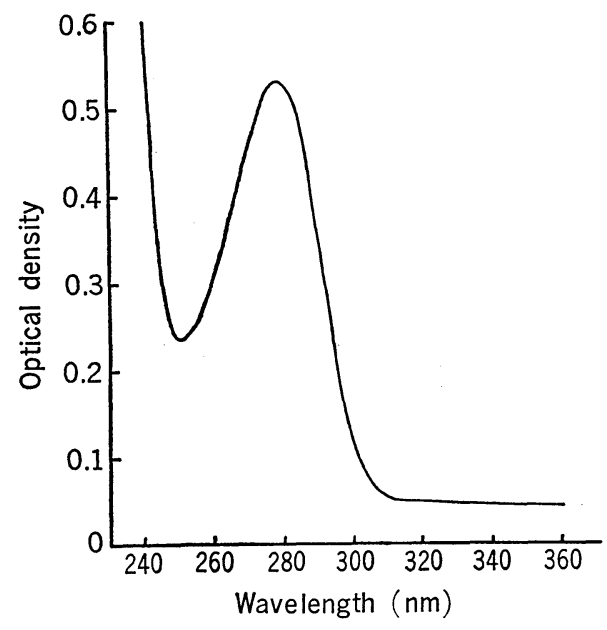

Fig. 6. Absorption spectrum of the dihydrofolate synthetase purified from pea seedlings. Protein concentration was $0.485 \mathrm{mg}$ per $\mathrm{ml}$.

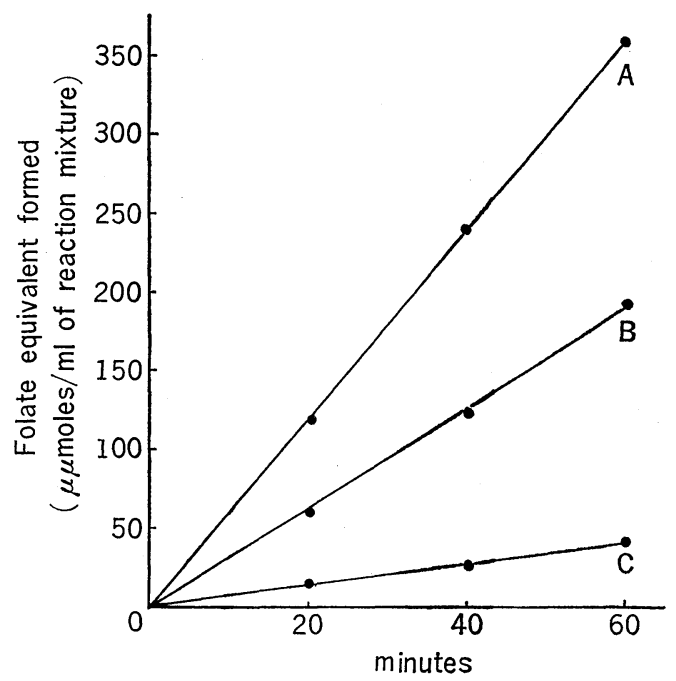

Fig. 7. Relationship between the time course of the reaction and enzyme concentrations. The standard assay procedure was used, except where altered reaction time and amounts of enzyme are indicated. A, $2.4 \mu \mathrm{g} ; \mathrm{B}, 1.2 \mu \mathrm{g} ; \mathrm{C}, 0.24 \mu \mathrm{g}$. 
Time course of the reaction

The time course of the reaction was tested at various concentrations of the enzyme. The reaction proceeded linearly and the amounts of folate equivalent formed were proportional to the amounts of enzyme preparation used, as shown in Fig. 7.

\section{Effect of pH on enzyme activity}

The effect of $\mathrm{pH}$ on enzyme activity is illustrated in Fig. 8. Tris- $\mathrm{HCl}$ and glycine- $\mathrm{NaOH}$ buffers were used at final concentrations of $0.1 \mathrm{M}$. Maximum activity was obtained at $\mathrm{pH}$ 8.8. This value is in agreement with the optimum $\mathrm{pH}$ obtained in a previous experiment using a crude enzyme preparation (3).

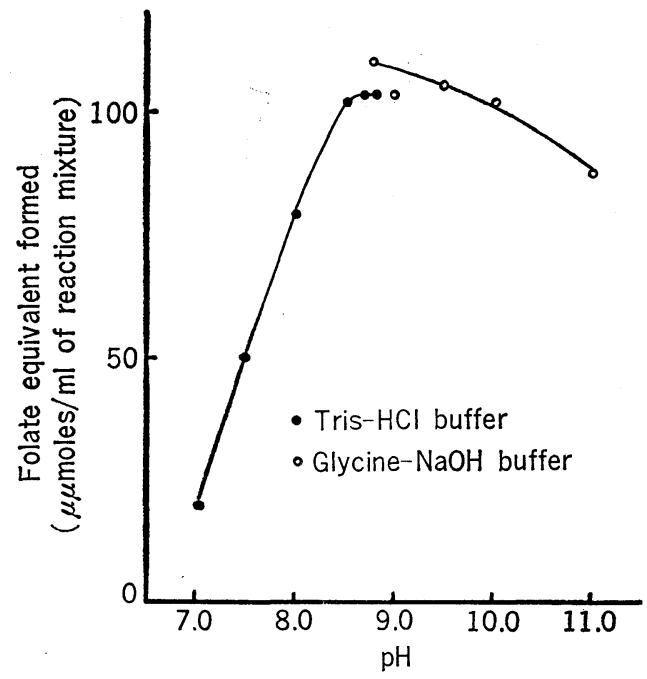

Fig. 8. Effect of $\mathrm{pH}$ on enzyme activity. Assay conditions were the same as those described in "MATerials AND Methods," except that various buffers at the indicated pH values were used at final concentrations of $0.1 \mathrm{M}$.

Table 2. Component study for dihydrofolate synthetase (I).

The standard assay method was used except for the omission of the indicated substances. The enzyme already contained $5 \mu$ moles of ammonium sulfate.

\begin{tabular}{lc}
\hline \multicolumn{1}{c}{ Omission } & Folate equivalent formed (pmoles) \\
\hline None & 108 \\
Dihydropteroate & 0 \\
L-Glutamate & 0 \\
ATP & 0 \\
Mg $^{2+}$ & 0 \\
K $^{+}$ & 23 \\
2-Mercaptoethanol & 74 \\
Enzyme & 0 \\
\hline
\end{tabular}


Table 3. Component study for dihydrofolate synthetase (II).

\begin{tabular}{llc}
\hline \multicolumn{1}{c}{ Omission } & \multicolumn{1}{c}{ Addition } & $\begin{array}{c}\text { Folate equivalent formed } \\
\text { (pmoles) }\end{array}$ \\
\hline None & None & 119 \\
Dihydropteroate & None & 0 \\
Dihydropteroate & Pteroate & 0 \\
Dihydropteroate & Tetrahydropteroate & 0 \\
ATP & None & 0 \\
ATP & ADP & 0 \\
ATP & AMP & 0 \\
ATP & GTP & 0 \\
ATP & ITP & 0 \\
ATP & CTP & 0 \\
ATP & UTP & 0 \\
\hline
\end{tabular}

${ }^{a}$ Incubation was performed at $37^{\circ} \mathrm{C}$ for $30 \mathrm{~min}$ in an argon atmosphere.

Table 4. Divalent cation requirements for dihydrofolate synthetase.

Each metal was used in the form of its sulfate.

\begin{tabular}{lcc}
\hline Divalent cations & Conc. (mM) & $\begin{array}{c}\text { Folate equivalent formed } \\
\text { (pmoles) }\end{array}$ \\
\hline None & 0 & 0 \\
$\mathrm{Mg}^{2+}$ & 1.0 & 53 \\
& $5.0^{\mathrm{a}}$ & 98 \\
$\mathrm{Mn}^{2+}$ & $0.5^{\mathrm{a}}$ & 124 \\
$\mathrm{Fe}^{2+}$ & 1.0 & 77 \\
$\mathrm{Co}^{2+}$ & 1.0 & 16 \\
$\mathrm{Zn}^{2+}$ & 1.0 & 6 \\
$\mathrm{Cu}^{2+}$ & 1.0 & 4 \\
$\mathrm{Ni}^{2+}$ & 1.0 & 0 \\
$\mathrm{Ca}^{2+}$ & 1.0 & 0 \\
\hline
\end{tabular}

a Optimal concentration.

Table 5. Univalent cation requirements for dihydrofolate synthetase.

The standard assay was used except that the enzyme was dialyzed against $0.01 \mathrm{M}$ Tris- $\mathrm{HCl}$ buffer at $\mathrm{pH} 7.5$ containing $0.05 \mathrm{M}$ of 2 -mercaptoethanol. $100 \mu$ moles of each metal was used in the form of the chloride.

\begin{tabular}{lc}
\hline \multicolumn{1}{r}{ Addition } & Folate equivalent formed (pmoles) \\
\hline None & 0 \\
$\mathrm{~K}^{+}$ & 108 \\
$\mathrm{NH}_{4}^{+}$ & 95 \\
$\mathrm{Rb}^{+}$ & 89 \\
$\mathrm{Na}^{+}$ & 8 \\
$\mathrm{Cs}^{+}$ & 5 \\
$\mathrm{Li}^{+}$ & 3 \\
\hline
\end{tabular}


Component study of the reaction. As shown in Table 2, the reaction was dependent on dihydropteroate, L-glutamate, $\mathrm{ATP}, \mathrm{Mg}^{2+}$, and the enzyme. Omission of $\mathrm{K}^{+}$or 2-mercaptoethanol from the complete system resulted in a decrease in the reaction velocity. This enzyme was specific for dihydropteroic acid as the substrate. Pteroic and tetrahydropteroic acids were not used as substrates. ATP was not replaceable with any other nucleotides, as shown in Table 3. GRIFFIN and BROWN (2) reported that in the partially purified enzyme from E. coli, ITP, GTP, and ADP could be utilized 60,35, and $10 \%$, respectively, as effectively as ATP. $K_{m}$ values for dihydropteroate, L-glutamate, and ATP were calculated as $1.0 \times 10^{-6}$ $1.5 \times 10^{-3}$ and $1.0 \times 10^{-4} \mathrm{M}$, respectively. These $K_{m}$ values are summarized in Table 6 .

Divalent cation requirements. The effect of various divalent cations on the enzyme activity was investigated using their sulfate forms. The results are shown in Table 4. $\mathrm{Mn}^{2+}$ was more effective than $\mathrm{Mg}^{2+}$ in promoting enzyme activity, and this effect could be replaced by $\mathrm{Fe}^{2+}$ to a lesser extent. $\mathrm{Mn}^{2+}$ was, however, only 10 to $15 \%$ as effective as $\mathrm{Mg}^{2+}$ in the partially purified enzyme from $E$. coli (2). $K_{m}$ values for $\mathrm{Mg}^{2+}$ and $\mathrm{Mn}^{2+}$ were calculated as $1.1 \times 10^{-3}$ and $6.3 \times 10^{-5} \mathrm{M}$, respectively, in the highly purified enzyme from pea seedlings. The $K_{m}$ value of the highly purified enzyme from pea seedlings had about a 5-fold decrease in comparison with that from the partially purified enzyme from pea seedlings for $\mathrm{Mn}^{2+}$. This presents the possibility that the enzyme activity might require $\mathrm{Mn}^{2+}$ rather than $\mathrm{Mg}^{2+}$ as the divalent cation in vivo.

Univalent cation requirement. The enzyme, dialyzed for $18 \mathrm{hr}$ against $0.01 \mathrm{M}$ Tris- $\mathrm{HCl}$ buffer at $\mathrm{pH} 7.5$ containing $0.01 \mathrm{~m} 2$-mercaptoethanol in the cold was used for the following experiments.

The effect of various univalent cations in their chloride forms on the enzyme activity was investigated at a final concentration of $100 \mathrm{~mm}$. The results are shown in Table 5. An absolute univalent cation requirement for enzyme activity was observed. $\mathrm{K}^{+}$was the most effective, and was replaceable by $\mathrm{NH}_{4}^{+}$and $\mathrm{Rb}^{+}$. $\mathrm{Na}^{+}, \mathrm{Li}^{+}$, and $\mathrm{Cs}^{+}$were not effective.

Table 6. Michaelis-Menten constant $\left(K_{m}\right)$ for the binding of the substrate.

\begin{tabular}{lc}
\hline \multicolumn{1}{c}{ Substrate } & $K_{m}$ \\
\hline Dihydropteroate & $1.0 \times 10^{-6} \mathrm{M}$ \\
L-Glutamate & $1.5 \times 10^{-3} \mathrm{M}$ \\
$\mathrm{ATP}$ & $1.0 \times 10^{-4} \mathrm{M}$ \\
$\mathrm{MgSO}_{4}$ & $1.1 \times 10^{-3} \mathrm{M}$ \\
$\mathrm{MnSO}_{4}$ & $6.3 \times 10^{-5} \mathrm{M}$ \\
\hline
\end{tabular}

Inhibition of the enzymatic reaction by $A D P$

The enzymatic reaction was inhibited by the addition of ADP, but not AMP, 
Table 7. The effect of ADP and AMP on the enzymatic formation of dihydrofolate.

\begin{tabular}{ccc}
\hline Addition & Conc. (mM) & Folate equivalent (pmoles) \\
\hline None & & 118 \\
ADP & 2.5 & 88 \\
& 5.0 & 64 \\
AMP & 2.5 & 112 \\
& 5.0 & 110 \\
\hline
\end{tabular}

as shown in Table 7. Furthermore, another experiment using the enzyme prepared from Serratia indica (12) detected ADP formed enzymatically from ATP using chromatographic procedures. This indicates that the product from ATP in the reaction was composed of $\mathrm{ADP}$ and $\mathrm{P}_{\mathrm{i}}$, as shown in the following equation:

Dihydropteroate + L-Glutamate $+\mathrm{ATP} \longrightarrow$ Dihydrofolate $+\mathrm{ADP}+\mathrm{P}_{\mathrm{i}}$.

The systematic name for dihydrofolate synthetase in plants should be 7,8dihydropteroate: L-glutamate ligase (ADP) in analogy with that in $E$. coli.

\section{REFERENCES}

1) IwaI, K., OKinaKa, O., and Suzuki, N., J. Vitaminol., 14, 160 (1968).

2) Griffin, M. J. and Brown, G. M., J. Biol. Chem., 239, 310 (1964).

3) Ikeda, M. and Iwai, K., Plant \& Cell Physiol., 11, 639 (1970).

4) Futterman, S., J. Biol. Chem., 228, 1031 (1957).

5) O’Dell, B. L., Vandenbelt, J. M., Bloom, E. S., and Pfiffner, J. J., J. Amer. Chem. Soc., 69, 250 (1947).

6) Lowry, O. H., Rosebrough, N. J., Farr, A. L., and Randall, R. J., J. Biol. Chem., 193, 265 (1951).

7) IwaI, K., OKinaKa, O., and Yokomizo, H., Vitamins (Japan), 35, 387 (1967).

8) Andrews, P., Biochem. J., 96, 595 (1965).

9) Fujiwara, A. and Iida, S., J. Sci. Soil \& Manure (Japan), 31, 467 (1960).

10) Iwai, K., Okinaka, O., Ikeda, M., and Suzuki, N., in K. IwaI, et al. (Editors), Chemistry and Biology of Pteridines, Maruzen Co., Tokyo, p. 281 (1970).

11) IKedA, M. and IwaI, K., J. Nutr. Sci. Vitaminol., 21, 1 (1975).

12) IKEDA, M. and IWAI, K. unpublished data. 